\title{
Marketing Themes and Topic: A Content Analysis of the Articles Published in the Top Marketing Journals from 2015 to 2020
}

\author{
Waleed Alawad
}

\section{ABSTRACT}

The purpose of this study is to investigate the most important themes and topics in the marketing field in the top of three published marketing journals: Journal of Marketing Research, Marketing Science, and Journal of Marketing. between 2015-2020, in order to identifying the marketing researchers' interest and topics in each theme.

With a reviewing a number of (1027) published articles in the selected articles between 2015 - 2020, the study found that the Journal of Marketing Research has got a share of $40 \%$ (420 articles) of the total published articles compared to $31 \%$ (318 articles) for the Marketing Science Journal, and 29\% (289 articles) for the Journal of Marketing.

The study resulted that the E- Marketing, advertising, consumer behavior, product development and pricing themes have got a share of $35 \%(363$ articles) of the total published articles of those three journals (1027) published articles.

E-Marketing has got the highest interest of the three top journals interest with a total of 97 published articles. Then advertising theme has got the second interest with 81 published articles each, and finally, consumer behavior and product development themes have got around 60 published articles.

However, the study showed that green marketing and international marketing themes had very week interest in the three journals with a total of five articles published in the selected journals between 2015-2020.

Keywords: analysis, articles, content, content analysis approach, marketing, marketing journals, research, themes, topics, trend.

\section{INTRODUCTION}

The huge number of new articles published daily in tens of marketing journals makes the marketing researchers necessary to filter out unimportant ones and detect groundbreaking new articles that bring new trends.

In discussing fruitful directions for future marketing research, it is important to study the nature of developments of basic research in marketing over the past years in order to develop the system that involves methodologies, databases, analytical and conceptual frameworks for further marketing development. The tremendous growth of marketing data has had a major impact on marketing practice by providing information about particular issues, however, the long run it is the development of a knowledge base that will yield the greatest returns to the investment made in marketing science [1].

The trends of marketing research are changing rapidly with the change of today business and economic environment so, it is very necessary for the marketing researchers to have a continuous overall content analysis of the published articles

\author{
Submitted : June 30, 2021 \\ Published : July 24, 2021 \\ ISSN: $2507-1076$ \\ DOI: $10.24018 /$ ejbmr.2021.6.4.962 \\ Waleed Alawad * \\ Department of Business Administration, \\ Qassim University, Qassim, Saudi Arabia. \\ (e-mail: mashaled ${ }^{\circledR}$ hotmail.com)
}

*Corresponding Author on the top marketing journals by following up the chain of marketing development in theory and practice, and the interrelationship between them in order to recognize what is going on in the marketing field concerning the business and economic world [2].

Diversity among research designs contributes to the understanding of marketing phenomena and the development of marketing theories and studies. Variety in research strategies, metrics, and methods introduces the chance to marketing researchers to qualify and improve theoretical relationships and to refine marketing theory. It is important for marketing researchers to examine trends in the research strategies, metrics, and methods employed in marketing research in order to present a conceptual framework that underscores benefits and limitations inherent to alternative research design [3].

The reviewing of marketing articles presents how marketing research has unfolded and developed over the last years, therefore it would be tempting and intellectually interesting to review the literature which intends to explore the main research themes and trends in the marketing field. It 
is highly important for marketing academics and researchers reviewing the marketing articles to know which marketing themes are most likely to be the winners and losers in terms of publication potential, significance, and academic standing, and the major trends in the future direction [4].

The current study reviewed the articles that been published in three top marketing journals which are: Journal of Marketing Research, Marketing Science, and Journal of Marketing. The study is an extension of previous research done by [2] who studied the themes and topics of marketing research by analyzing the articles published in the same three journals between 2010 and 2014.

The current study is important to marketing academics and researchers to get awareness to what are the major themes of marketing were focused on by the marketing researchers during the period of 2015-2020 in the top marketing journals in order to have a clear statement of the most important topics as well as neglected topics that marketing authors focused on during these years which may unveil the required marketing themes and topics that must been studied for future research.

The current study aimed to analyze articles that been published in the top three marketing journals to figure out what the major marketing topics were focused on by marketing researchers during the period between 2015 to 2020 for three reasons:

- The result of the study will be measured with the previous two studies that been done by [1] who investigated the themes and topics in the same selected three marketing journals from 2010 to 2014 and [4]who did a study that focused on marketing research themes and trends between 2000 and 2009.

- It gives marketing researchers a view of the trends marketing topics and which topics get more interest.

- A chance for marketing researchers to be focused more on these neglected marketing topics .

This study tried to answer questions that regarding what and how many topics were published in three top marketing journals by introducing the main topics that the researchers have given the interest in during the period from 2015 to 2020 ?

\section{PREVIOUS STUdY}

Back in 1994, Bush and Grant did the first study that analyzed 358 articles published in four marketing journals between 1980-1992 with 18 themes. The paper was analyzed to identity the direction in which researchers are interesting in the field of force management [5].

In 2008, Dahlstorm et al examined presented diversity as a procedure to examine the likelihood that research in marketing contributes to the practice and theory by reviewing around 844 marketing articles that were published in twoperiod times between 1986 and 1990, and between1996 and 2000 in two marketing journals: Journal of Marketing and Journal of Marketing research. The study showed the diversity were week among strategies, measures, and methods employed in marketing research [3].

Later on, 2010, Yadav investigated the articles published over 30 years between 1978 and 2007 in four marketing journals: Journal of Marketing Research, Journal of
Consumer Research, Marketing Science, and Journal of the Academy of Marketing Science. The researcher indicated that conceptual articles in marketing journals are sharply decreasing especially in the Journal of Marketing (JM) [6].

Collesei et al analyzed 250 articles published between 2007 and 2009 from three marketing journals (Marketing Science, Journal of Marketing, European Journal of Marketing). The Study identified 12 marketing themes which are: branding, retail and distribution, consumer behavior, marketing research, sales, Internet, marketing strategy, communication, customer satisfaction, product services [7].

Haji-Basri did a study that been focusing on marketing themes and trends. The purpose of the study was to identify the marketing themes by analyzing a number of 1322 research published in three marketing journals: The Journal of Marketing, Marketing Science Journal, and Journal of Marketing Research in a period of nine years between 2000 and 2009. The study used the content analysis method and classified the marketing themes into 21 themes: consumer behavior, management and planning, pricing, marketing function and strategy, new product development, branding, electronic marketing and information technology, research methodology, theory and philosophy of science, advertising, sales (promotion/management), distribution, customer satisfaction; legal, political, and economic issues; ethics and social responsibility, services, loyalty, value creation, retailing, international and comparative. The study resulted that consumer behavior, management, and planning, pricing, market function/strategy, and new product development were the most popular research themes within these year [4].

Hamid Salih investigated the themes of marketing in articles published in three marketing journals: Journal of Marketing Research, Marketing Science journal, and Journal of Marketing from 2010 to 2014 in order to identifying the researchers' interests and topics in each theme. The study noted that the Journal of Marketing Research has got a share of $39 \%$ of the total published articles and $35 \%$ for the Marketing Science journal, and $26 \%$ for the Journal of Marketing .By analyzing a total of 22 marketing themes, the study showed that extensive interest has been given to consumer behavior at $22 \%$, e-marketing at $10 \%$, advertising at $7 \%$, promotion and pricing at $7 \%$ each, product development at 5\%, and marketing management at 4\% [2].

Pe 'rez-Villarreal et al analyzed a number of 1169 articles that been published in two main marketing journals: Journal of Marketing Research and the Journal of Marketing for a period of nine years from the year of 2005 to 2014 .The article used statistical methods to find out the most relevant themes of these two journals as well as the most influential articles. With a number of 24 themes that been used in the study, the study found that topics been focusing on consumers and customers are the main topics of these marketing research journals, which underlines the increasing attention in consumers and consumer behavior [6].

To conclude a list for research theme the previous similar studies were reviewed as shown in Table I. 
TABLE I: SUMMARY OF SIMILAR PREVIOUS STUdIES

\begin{tabular}{|c|c|c|c|c|c|c|c|}
\hline Sir & Study & The Year & $\begin{array}{l}\text { Time } \\
\text { Period }\end{array}$ & $\begin{array}{l}\text { Number of } \\
\text { themes }\end{array}$ & $\begin{array}{l}\text { Number of } \\
\text { covered } \\
\text { articles }\end{array}$ & $\begin{array}{l}\text { Articles } \\
\text { covered }\end{array}$ & Major Finding \\
\hline 1 & $\begin{array}{l}\text { Bush and Grant } \\
\text { [5] }\end{array}$ & 1994 & 1980-1992 & 18 & 4 & 358 & $\begin{array}{c}\text { More rigorous and scientific research on sales } \\
\text { field. }\end{array}$ \\
\hline 2 & $\begin{array}{l}\text { Dahlstorm et al. } \\
\text { [3] }\end{array}$ & 2008 & $\begin{array}{l}1986-1990 \\
1996-2000\end{array}$ & 12 & 2 & 884 & $\begin{array}{l}\text { the diversity among strategies, measures, and } \\
\text { methods employed were limited. }\end{array}$ \\
\hline 3 & $\begin{array}{l}\text { Collesei et al., } \\
\text { [7] }\end{array}$ & 2010 & 2007-2009 & 12 & 250 & 250 & $x_{0}$ \\
\hline 4 & Yadav [6] & 2010 & $1978-2007$ & 22 & 4 & - & $\begin{array}{c}\text { Conceptual articles in marketing journals are } \\
\text { sharply decreasing especially in the Journal of } \\
\text { Marketing. }\end{array}$ \\
\hline 5 & $\begin{array}{l}\text { Myongjee et al } \\
{[8]}\end{array}$ & 2011 & 2000-2009 & 18 & 4 & 570 & $\begin{array}{l}\text { Decrease in conceptual articles. High percentage } \\
\text { of conceptual articles on management, planning, } \\
\text { and strategy. }\end{array}$ \\
\hline 6 & Haji-Basri [4] & 2012 & 2000-2009 & 21 & 3 & 1322 & $\begin{array}{l}\text { Consumer behavior, management, and planning, } \\
\text { pricing, market function/strategy, and new } \\
\text { product development were the five most popular } \\
\text { research themes within these years. }\end{array}$ \\
\hline 7 & $\begin{array}{l}\text { Abdel Hamid, } \\
\quad[2]\end{array}$ & 2016 & 2010-2014 & 22 & 3 & - & $\begin{array}{l}\text { Journal of Marketing Research has got a share } \\
\text { of } 39 \% \text { compared to } 35 \% \text { for the Marketing } \\
\text { Science journal, and } 26 \% \text { for the Journal of } \\
\text { Marketing. Extensive interest has been given to } \\
\text { consumer behavior at } 22 \text {. }\end{array}$ \\
\hline 8 & $\begin{array}{l}\text { Barahona, Igor, } \\
\quad \text { et al [9] }\end{array}$ & 2018 & 2005-2014 & 24 & 2 & 1069 & $\begin{array}{l}\text { Consumers and customers topics are the main } \\
\text { topics of these marketing research journals. } \\
\text { There is increasing attention in consumers and } \\
\text { consumer behavior. }\end{array}$ \\
\hline
\end{tabular}

\section{METHODOlOGY}

The current study is an extension of previous study done by Abdel Hamid [2] who studied the marketing themes and topics between 2010 and 2014 in the same selected three marketing journals. The main data of the current study were relied on the three top marketing journals: Journal of Marketing, Journal of Marketing Research, and Marketing Science that have been published between the years of 2015 to 2020 The study used the content analysis approach to investigate the topics of marketing in the selected marketing journals.

The current study was depended on the selected published articles by browsing the title, abstract and keywords of each article to identify the article topic in order to figure out which theme should the topic be included. The marketing topics in the study was classified into 25 themes which are near the classification of Abdel Hamid [1] and Haji-Basri [4]. The 25 themes that been used in the current study were: consumer behavior, E-Marketing, Advertising, Branding, Research methods, Promotion, Pricing, Product Development, Marketing Management, Sales Management, Retailing, Channels of Distribution, Value Creation, Customer Satisfaction, Service Quality, Competitive Analysis, Customer Relationship, International Marketing, Social Responsibility, Customer Loyalty, Green Marketing, Consumer Performance, Marketing communication and Marketing Ethics. The study used classification "others" as a theme number 25 to be named to the topics that are not related to the previous themes.

The study counted the rates of each theme in the three journals by identifying the topics in each theme and presented the results in four parts .

1. The overall numbers of the journal's publications in each theme (Table II).

2. The overall percentage of the journal's share of publications in each theme (Table III).
3. Compared to the current study result with previous studies, especially the studies that been don by Abdel Hamid [2] and Haji-Basri [4] (Table IV and Table V).

4. The study finally has set a table that presented the main marketing topics that been published in the articles in each theme which give the marketing researchers to have a quick knowledge on the main marketing topics that have been investigated more or less in order to be as a base for future research (Table VI).

\section{DISCUSSION}

Table II represents the number of 25 majors marketing themes that have been focused on the three Marketing Journals between 2015 and 2020. And Table III shows the percentage of articles that have been written in each theme.

The Table I and Table II show Some important findings as follows :

1. Firstly, between 2015 to 2020 , a number of 709 articles have been published in the three marketing journals. The Journal of Marketing got the lowest share of the total articles that have been published between 2015 and 2020 at a percentage of $29 \%$ (289 articles), then, the journal of Marketing Science at $31 \%$, (318 articles) and the Journal of Marketing research got the highest share at $40 \%$. (420 articles).

2. In general, comparing between the three journals, journal of marketing research has got more attention in EMarketing, consumer behavior, customer relationship and sales management with a number of (117) articles which represent $28 \%$ form the all publish articles in the same journal. The researchers in the journal of marketing science have got more attention in E- Marketing, advertising and pricing with a number of (105) articles which represent $33 \%$ form the all publish articles in the same journal. However, journal of marketing has got more attention in E- Marketing, 
product development, branding, customer relationship and marketing management with a number of (115) articles which represent $39 \%$ form all publish articles in the same journal.

TABLE II: THE NUMBER OF MARKETING THEMES THAT BEEN FOCUSED IN THE THREE MARKETING JOURNALS

\begin{tabular}{|c|c|c|c|c|c|}
\hline Ser & Themes & $\begin{array}{l}\text { Journal of } \\
\text { Marketing }\end{array}$ & $\begin{array}{c}\text { Journal of } \\
\text { Marketing } \\
\text { Science }\end{array}$ & $\begin{array}{c}\text { Journal of } \\
\text { Marketing } \\
\text { Research }\end{array}$ & Total \\
\hline 1 & E-Marketing & 26 & 39 & 32 & 97 \\
\hline 2 & Advertising & 13 & 41 & 27 & 81 \\
\hline 3 & Product Development & 23 & 20 & 24 & 67 \\
\hline 4 & Consumer Behavior & 11 & 8 & 41 & 60 \\
\hline 5 & Pricing & 11 & 25 & 22 & 58 \\
\hline 6 & Research Methods & 14 & 15 & 20 & 49 \\
\hline 7 & Branding & 22 & 11 & 16 & 49 \\
\hline 8 & Customer Relationship & 23 & 12 & 5 & 40 \\
\hline 9 & Sales Management & 12 & 5 & 21 & 38 \\
\hline 10 & Promotion & 4 & 10 & 23 & 37 \\
\hline 11 & $\begin{array}{l}\text { Consumer } \\
\text { Performance }\end{array}$ & 2 & 9 & 24 & 35 \\
\hline 12 & Competitive Analysis & 7 & 17 & 10 & 34 \\
\hline 13 & $\begin{array}{c}\text { Marketing } \\
\text { Management }\end{array}$ & 21 & 6 & 6 & 33 \\
\hline 14 & Social Responsibility & 9 & 6 & 5 & 20 \\
\hline 15 & Customer Satisfaction & 14 & 2 & 1 & 17 \\
\hline 16 & $\begin{array}{l}\text { Channels of } \\
\text { Distribution }\end{array}$ & 5 & 10 & 2 & 17 \\
\hline 17 & Retailing & 3 & 5 & 5 & 13 \\
\hline 18 & Value Creation & 1 & 2 & 0 & 3 \\
\hline 19 & Service Quality & 4 & 1 & 5 & 10 \\
\hline 20 & Customer Loyalty & 4 & 2 & 4 & 10 \\
\hline 21 & Marketing Ethics & 4 & 5 & 1 & 10 \\
\hline 22 & $\begin{array}{c}\text { Marketing } \\
\text { Communication }\end{array}$ & 3 & 0 & 3 & 6 \\
\hline 23 & Green Marketing & 3 & 0 & 2 & 5 \\
\hline 24 & $\begin{array}{c}\text { International } \\
\text { Marketing }\end{array}$ & 0 & 0 & 0 & 0 \\
\hline 25 & Others & 50 & 67 & 121 & 238 \\
\hline- & Total & 289 & 318 & 420 & 1027 \\
\hline
\end{tabular}

TABLE III: Overall Percentages of MARKeting Themes THAT BeEN FOCUSED IN THE THREE MARKETING JOURNALS

\begin{tabular}{|c|c|c|c|c|c|}
\hline Ser & Themes & $\begin{array}{l}\text { Journal of } \\
\text { Marketing }\end{array}$ & $\begin{array}{c}\text { Journal of } \\
\text { Marketing } \\
\text { Science }\end{array}$ & $\begin{array}{c}\text { Journal of } \\
\text { Marketing } \\
\text { Research }\end{array}$ & Total \\
\hline 1 & E-Marketing & $26 \%$ & $40 \%$ & $34 \%$ & $9 \%$ \\
\hline 2 & Advertising & $16 \%$ & $51 \%$ & $33 \%$ & $8 \%$ \\
\hline 3 & Product Development & $34 \%$ & $30 \%$ & $36 \%$ & $6 \%$ \\
\hline 4 & Consumer Behavior & $18 \%$ & $13 \%$ & $69 \%$ & $6 \%$ \\
\hline 5 & Pricing & $19 \%$ & $43 \%$ & $38 \%$ & $6 \%$ \\
\hline 6 & Research Methods & $28 \%$ & $31 \%$ & $41 \%$ & $5 \%$ \\
\hline 7 & Branding & $45 \%$ & $22 \%$ & $33 \%$ & $4 \%$ \\
\hline 8 & Customer Relationship & $57 \%$ & $30 \%$ & $13 \%$ & $4 \%$ \\
\hline 9 & Sales Management & $32 \%$ & $13 \%$ & $55 \%$ & $4 \%$ \\
\hline 10 & Promotion & $11 \%$ & $27 \%$ & $62 \%$ & $4 \%$ \\
\hline 11 & Consumer Performance & $6 \%$ & $26 \%$ & $68 \%$ & $3 \%$ \\
\hline 12 & Competitive Analysis & $21 \%$ & $50 \%$ & $29 \%$ & $3 \%$ \\
\hline 13 & Marketing Management & $63 \%$ & $18 \%$ & $19 \%$ & $3 \%$ \\
\hline 14 & Social Responsibility & $45 \%$ & $30 \%$ & $25 \%$ & $2 \%$ \\
\hline 15 & Customer Satisfaction & $83 \%$ & $12 \%$ & $5 \%$ & $2 \%$ \\
\hline 16 & Channels of Distribution & $29 \%$ & $59 \%$ & $12 \%$ & $2 \%$ \\
\hline 17 & Retailing & $23 \%$ & $39 \%$ & $38 \%$ & $1 \%$ \\
\hline 18 & Value Creation & $33 \%$ & $67 \%$ & $0 \%$ & $1 \%$ \\
\hline 19 & Service Quality & $40 \%$ & $10 \%$ & $50 \%$ & $1 \%$ \\
\hline 20 & Customer Loyalty & $40 \%$ & $20 \%$ & $40 \%$ & $1 \%$ \\
\hline 21 & Marketing Ethics & $40 \%$ & $50 \%$ & $10 \%$ & $1 \%$ \\
\hline 22 & $\begin{array}{c}\text { Marketing } \\
\text { Communication }\end{array}$ & $50 \%$ & $0 \%$ & $50 \%$ & $1 \%$ \\
\hline 23 & Green Marketing & $60 \%$ & $0 \%$ & $40 \%$ & $0.5 \%$ \\
\hline 24 & International Marketing & $0 \%$ & $0 \%$ & $100 \%$ & $0.5 \%$ \\
\hline 25 & Others & $21 \%$ & $28 \%$ & $51 \%$ & $23 \%$ \\
\hline- & Total & $29 \%$ & $31 \%$ & $40 \%$ & $100 \%$ \\
\hline
\end{tabular}

TABLE IV: COMPARISON BETWEEN HAJI-BASRI [3], HAMID SALIH [1] AND THE CURRENT STUDY

\begin{tabular}{ccccc}
\hline Ser & Study & $\begin{array}{c}\text { Time } \\
\text { Period }\end{array}$ & $\begin{array}{c}\text { Number of } \\
\text { themes }\end{array}$ & $\begin{array}{c}\text { Number of } \\
\text { covered } \\
\text { articles }\end{array}$ \\
\hline 1 & Haji-Basri [4] & $2000-2009$ & 21 & 3 \\
2 & Hamid Salih [2] & $2010-2014$ & 22 & 3 \\
3 & Current Study & $2015-2020$ & 25 & 3 \\
\hline
\end{tabular}

TABLE V: THE TOP THREE THEMES COMPARISON BETWEEN HAJI-BASRI [3], HAMID SALIH [1] AND THE CURRENT STUDY

\begin{tabular}{cccc}
\hline $\begin{array}{c}\text { The } \\
\text { Rank }\end{array}$ & Haji-Basri [3] & Abdel Hamid [1] & Current Study \\
\hline 1 & Consumer Behavior & $\begin{array}{c}\text { Consumer } \\
\text { Behavior }\end{array}$ & $\begin{array}{c}\text { Advertising } \\
\text { E-Marketing and } \\
\text { Customer } \\
\text { Relationship } \\
\text { Product }\end{array}$ \\
3 & $\begin{array}{c}\text { Management and } \\
\text { planning }\end{array}$ & E-Marketing & $\begin{array}{c}\text { Pevelopment and } \\
\text { Pricing }\end{array}$ \\
\hline
\end{tabular}

3. E- Marketing theme has got the highest percentage of researchers' attention, which representing $9 \%$ of the marketing articles on all the marketing themes. In details, the researchers in journal of Marketing Science were interested more in the E- Marketing topic with $40 \%$, then the Journal of Marketing Research's share 34\%, while the journal of Marketing Science accounted for 26\%. E-Marketing can be viewed as a new philosophy in the last years that change the modern organization practice to be involved with the marketing of goods, services, information and ideas via the Internet and other electronic means (digital technologies) [10].

4. Advertising theme represented for $8 \%$ of all the published articles in the three marketing journals. In details, the Marketing Science journal has got the highest percentage which accounted for $51 \%$ of the published articles, and $33 \%$ in the Journal of Marketing Research and $16 \%$ in the Journal of Marketing.

5. Research on the consumer behavior was the fourth interesting theme with $6 \%$ of all the articles published in the three marketing journals. The theme has got high concentration from The Journal of Marketing Research at $69 \%$ of the published articles, then comes journal of Marketing with a little share at $18 \%$, and the Journal of Marketing Science at $13 \%$.

6. Pricing articles represented $6 \%$ of all the published articles in the three journals. The Journal of Marketing has had the highest share at $43 \%$, then, the Journal of Marketing Research and the journal of Marketing Science have got similar attention with around $40 \%$, and the Journal of Marketing was a little attention on the theme with only $19 \%$.

7. The articles that were interested in research methods theme represented for $5 \%$ of published articles in the three journals. The Journal of Marketing Research has the largest percentage of $41 \%$, then comes the Journal of Marketing Science at $31 \%$, and finally the Journal of Marketing at $28 \%$.

8. Branding, Customer relationship, sales management and promotion themes have been paid a similarity balanced attention for $5 \%$ of published articles in the three journals. The articles on these themes ranged between $11 \%$ and $57 \%$. In details, promotion and sales management themes have been paying more attention in the Journal of Marketing Research at $62 \%$ and $55 \%$, and the customer relationship 
were more focused in the journal of Marketing at $57 \%$ and While branding theme accounted $45 \%$ in the Journal of Marketing .

9. Consumer performance, competitive analysis and marketing management themes have been paid a similarity balanced attention for $3 \%$ of published articles in the three journals. Consumer performance theme have bas paying more attention in the Journal of Marketing Research at 68\%, and the marketing management was more focused in the journal of Marketing at $63 \%$, while competitive analysis theme accounted $63 \%$ in the Journal of Marketing .

10. The rest of themes represented weak percentage such as: retailing, value creation, service quality, customer loyalty, marketing ethics, marketing communication. Each of these themes has got a share of $1 \%$ only. However, other themes have got a slightly better share of $2 \%$ per each, which are: social responsibility, customer satisfaction and channels of distribution.

11. In summary, the three journals published (709) articles between 2015-2020. It can be clearly seen that, the journal of Marketing research has published more articles on consumer behavior, product development, sales management, promotion, consumer performance and service quality. The Journal of marketing science has published more articles on E- Marketing, pricing, competitive analysis, channels of distribution and value creation. However, the Journal of Marketing has published more articles on branding, customer relationship, marketing management and customer satisfaction.

Compared to previous studies, especially a studied that been don by Abdel Hamid [2] and Haji-Basri [4] who investigated the same articles that the current study did with different period as shown below in Table IV, and interesting results that been presented in the Table $\mathrm{V}$.

Table VI shows that Consumer behavior were the most interested theme in Haji-Basri study [4] and Abdel Hamid study [2] for almost 14 years between 2000 to 2014. However, the theme is not been interested in the current study because Advertising theme were the most interested theme. E- Marketing themes were still the second interested theme in Abdel Hamid study [2] and the current study.

TABLE VI: RESEARCH TOPICS IN MARKETING THEMES THAT BEEN Discussed INT THE THREE ARTICLES

\begin{tabular}{|c|c|c|c|c|}
\hline Ser & Themes & Journal of Marketing & $\begin{array}{c}\text { Journal of Marketing } \\
\text { Science }\end{array}$ & Journal of Marketing Research \\
\hline 1 & Consumer Behavior & $\begin{array}{l}\text { - Consumer Preferences } \\
\text { - Planned Purchase Behavior }\end{array}$ & $\begin{array}{l}\text { - Consumer } \\
\text { Complaining Behavior }\end{array}$ & $\begin{array}{l}\text { - Behavioral Experiments } \\
\text { - Innovation Behavior } \\
\text { - Encourage Desired Behaviors } \\
\text { - present behaviors } \\
\text { - Purchase Intention } \\
\text { - Purchase Behavior } \\
\text { - Attention, Information Processing }\end{array}$ \\
\hline 2 & E-Marketing & $\begin{array}{l}\text { - Online Searching } \\
\text { - Electronic Word-of-Mouth } \\
\text { Elasticity } \\
\text { - Online Idea } \\
\text { - Online Shopping Behavior } \\
\text { - Online Relationship } \\
\text { - Mobile Apps } \\
\text { - Online Purchasing } \\
\text { - Online Customers }\end{array}$ & $\begin{array}{l}\text { - Value of Online } \\
\text { Reviews } \\
\text { - Mobile Ad } \\
\text { Effectiveness } \\
\text { - Social Network Data } \\
\text { - Twitter Social } \\
\text { Networks }\end{array}$ & $\begin{array}{l}\text { - Online Community Environment } \\
\text { - Mobile Phone Coupons } \\
\text { - The Effect of Electronic Word of } \\
\text { Mouth } \\
\text { - Social Media, and Mobile } \\
\text { Marketing. } \\
\text { - Online Grocery Shopping } \\
\text { - Online Consumer Discussions } \\
\text { - Email Marketing Program }\end{array}$ \\
\hline 3 & Advertising & $\begin{array}{l}\text { - National Advertising } \\
\text { - Ad-Supported Media Platforms } \\
\text { - Mobile Advertising } \\
\text { - Tv Advertising }\end{array}$ & $\begin{array}{l}\text { - Advertising Exposures } \\
\text { - Keyword Search } \\
\text { Advertising } \\
\text { - Paid Search } \\
\text { Advertising } \\
\text { - Advertising Content }\end{array}$ & $\begin{array}{l}\text { - Advertising Effectiveness } \\
\text { - Planned Advertising } \\
\text { - Advertising Reform }\end{array}$ \\
\hline 4 & Research Methods & $\begin{array}{l}\text { - Marketing Research } \\
\text { - Marketing Analytics } \\
\text { - A Meta-Analytic Test of a } \\
\text { Theoretical Framework } \\
\text { - An Empirical Investigation in the } \\
\text { Automobile Industry. } \\
\text { - Integrating Theory and Practice } \\
\text { in Marketing } \\
\text { - A Theory of Customer Valuation } \\
\text { - A Theories-in-Use Approach to } \\
\text { Building Marketing Theory }\end{array}$ & & - Qualitative Marketing Research \\
\hline 5 & Promotion & $\begin{array}{l}\text { - Process Promotional Messages } \\
\text { - Price Promotions } \\
\text { - Word-of-Mouth }\end{array}$ & $\begin{array}{l}\text { - Exchange Promotions } \\
\text { - Marketing Campaigns }\end{array}$ & $\begin{array}{l}\text { - Word-of-Mouth Recommendations } \\
\text { - Word of Mouth's Impact } \\
\text { - Promoting Similarity } \\
\text { - Word-of-Mouth Dynamics }\end{array}$ \\
\hline 6 & Pricing & $\begin{array}{l}\text { - Price Discount } \\
\text { - Perceived Price Fairness } \\
\text { - Price Sensitivity }\end{array}$ & $\begin{array}{l}\text { - New Product Pricing } \\
\text { - Price Reactions } \\
\text { - Promotion Spillovers } \\
\text { - Behavioral Price } \\
\text { Discrimination }\end{array}$ & $\begin{array}{l}\text { - Price War } \\
\text { - Price transparency } \\
\text { - retail prices } \\
\text { - Price Memory } \\
\text { - Price Sensitivity }\end{array}$ \\
\hline
\end{tabular}


- Price Discount

- Price Negotiations

$\begin{array}{ll}7 & \begin{array}{l}\text { Product } \\ \text { Development }\end{array} \\ & \\ & \\ 8 & \begin{array}{l}\text { Marketing } \\ \text { Management }\end{array} \\ & \\ 9 & \text { Sales Manageme } \\ & \\ & \\ 10 & \text { Retailing } \\ & \\ 11 & \text { Value Creation } \\ 12 & \begin{array}{l}\text { Customer } \\ \text { Satisfaction }\end{array} \\ & \text { Service Quality } \\ 13 & \text { Competitive } \\ 14 & \begin{array}{l}\text { Analysis } \\ \text { Customer } \\ 15\end{array} \\ & \text { Relationship } \\ & \end{array}$

17 Channels of

Distribution

Marketing

Responsibility

Marketing Ethics
International

Social

Customer Loyalty

Green Marketing

Marketing

Communication

Branding

- New Product Development

- New Product Outcomes

- New Product Design

- New Product Creativity

- New Product Development

- Product Concept

- Product Innovation

- New Product Releases

- New Product Performance

- Evolution of Marketing

- Marketing Department Power

- Marketing Assessing

Performance

- Sales Organization

- Motivating Sales

- Sales Success

- Sales Performance

- Conflict between Retailer and

Manufacturer

- Supplier Shareholder Value

- Consumers Appreciation

- customer matters

- Consumer Preferences

- Service Encounters

- Competitive Disadvantages

- Customer Relationship Quality

- Consumers' Adoption

- Consumers' Response

- Regaining "Lost" Customers

- Customer Orientation

- Engaging Customers

- Consumer Response

- Business Customers

- Dynamic Relationship Marketing

- Customer Journey

- Creating Customer Value

- New Customer Acquisition

- Franchised Marketing Channels

- Channel Partner Management

- Social networks

- Trust and Persuasiveness

- Moral and Social Resources

- Moral and Competent Service

Providers

- Ethical Company Production

Practices

- Greenness of Products

- Shopping Bags

- Green Programs

- Strategic Brand Management

- Branding Strategies

- Brand Sabotage

- Brand Consistency

- Brand Information

- Brand Alliances

- Customer-Brand Relationships

- Customer Data

Performance
- Competitive Markets

- Product Competition

- Customer Loyalty Programs
- New Product
Launches

- Marketing Instruments

- Product Sales

- Salespeople

- Sales Executives in B-2-B Markets

- Sales Force
- Service Amenities

- Service Robots

- Competitive Advantage

- Competitive Intelligence:

- Customer Relationship Management
- Social Effects

- Social Interactions

- Loyalty Program

- Ethics Committees and Consultation
- Building Entertainment Brands

- Luxury Brands

- Brand Image
- Persuasive Communication

- Fitness Branding

- Brand Name

- Brand Image

- Brand Improvement

- Bodied Brand

- Brand Equity

- Luxury Brands

- Consumer Reviews

- Consumer Choice

- Customer Participation

- Willingness to Donate 


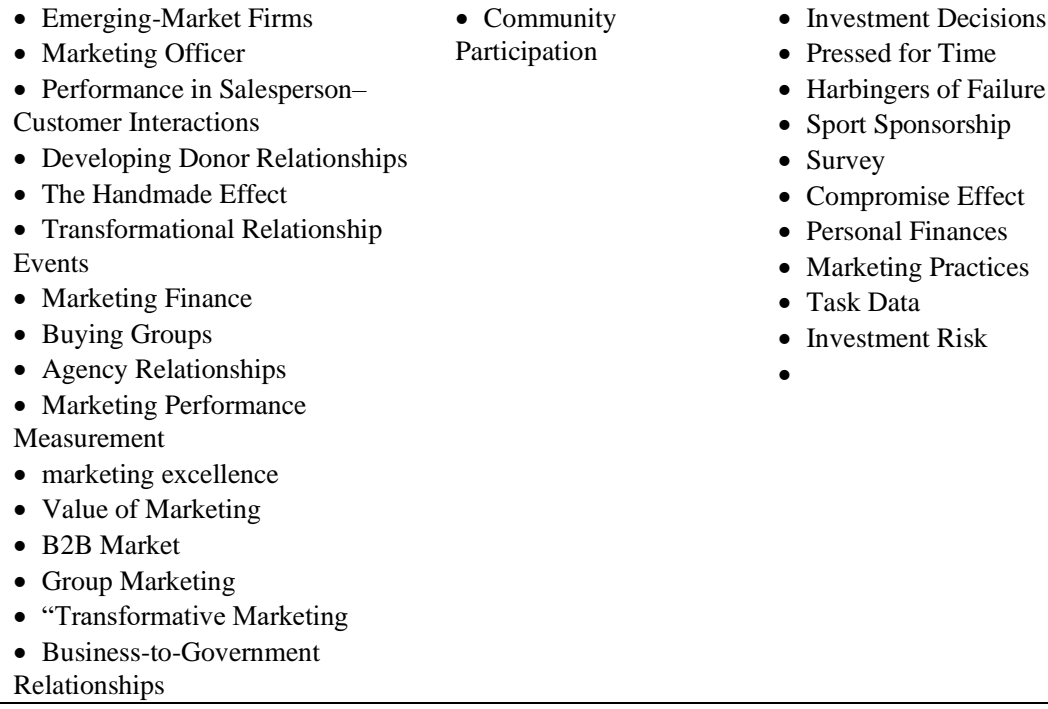

- Marketing Officer

- Performance in Salesperson-

- Community

- Investment Decisions

Customer Interactions

- Developing Donor Relationships

Participation

- Pressed for Time

- The Handmade Effect

Harbingers of Failure

- Sport Sponsorship

- Transformational Relationship

Events

- Marketing Finance

- Buying Groups

- Agency Relationships

- Marketing Performance

Measurement

- marketing excellence

- Value of Marketing

- B2B Market

- Group Marketing

- "Transformative Marketing

- Business-to-Government

Relationships

\section{LIMITATION}

- The study is limited to the publication of three marketing journals: Journal of Marketing Research, Marketing Science, and Journal of Marketing between 2015 2020. Adding other marketing journals may give a different result.

- The study was classifying the article topics on the selected articles based on the research personal decision who tried to be more attention on the main topic in each article by carefully reading each article to use the topic to be selected in accurate theme.

- The study used the main idea of the articles to select the accurate topic specially to some topic may use tow themes such as Promotional Price, Commercial, Online advertising and so on.

\section{REFERENCES}

[1] Bass, Frank M. "The future of research in marketing: marketing science." (1993): 1-6.

[2] Saleh, Mahmoud Abdel Hamid. "Themes and topics of research in marketing: A content analysis of the articles published in three marketing journals." International Journal of Business Administration 7.1 (2016): 12

[3] Dahlstrom, Robert, Arne Nygaard, and Jody L. Crosno. "Strategic, metric, and methodological trends in marketing research and their implications for future theory and practice." Journal of Marketing Theory and Practice 16.2 (2008): 139-152.

[4] Haji-Basri, M. "Marketing research contemporary themes and trends." Interdisciplinary Journal of Contemporary Research in Business 4.5 (2012): 17-24.

[5] Bush, Alan J., and E. Stephen Grant. "Analyzing the content of marketing journals to assess trends in sales force research: 19801992." Journal of Personal Selling \& Sales Management 14.3 (1994): 57-68.

[6] Yadav, Manjit S. "The decline of conceptual articles and implications for knowledge development." Journal of Marketing 74.1 (2010): 1-19.

[7] Collesei, U., Andreani, J., Conchon, F., Halliburton, C., Koshy, A., Lu, T., ... Wiedmann, K. Marketing trends: Toward new research perspectives. Journal of Marketing trends, 1(2), (2010) 5-6.

[8] Yoo, Myongjee, Sojung Lee, and Billy Bai. "Hospitality marketing research from 2000 to 2009: topics, methods, and trends." International Journal of Contemporary Hospitality Management (2011).

[9] Barahona, Igor, et al. "Identifying research topics in marketing science along the past decade: a content analysis." Scientometrics 117.1 (2018): 293-312

[10] El-Gohary, Hatem. "E-Marketing-A literature Review from a Small Businesses perspective." International journal of business and social science 1.1 (2010). 